$$
\text { No 1-APRIL } 1961
$$

\title{
THE
}

\section{INTERNATIONAL REVIEW OF THE}

\section{RED CROSS}

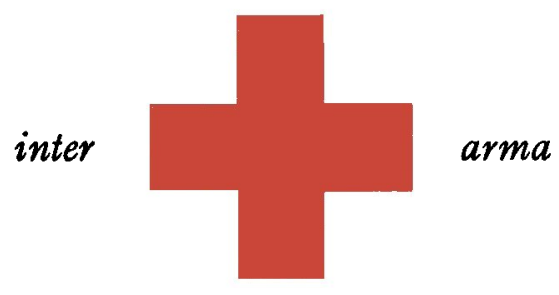

caritas

INTERNATIONAL COMMITTEE OF THE RED CROSS GENEVA 


\title{
INTERNATIONAL REVIEW OF THE RED CROSS
}

\author{
FIRST YEAR - No. 1 \\ APRIL 1961 \\ * \\ CONTENTS
}

English Edition of the Revue internationale . . . . . . . . . . . . 3

G.I.A.D, Draper, LL.M.: Penitential discipline and Public Wars in the Middle Ages (I) . . . . . . . . . . . . . . . . . . . . . . . 4

INTERNATIONAL COMMITTEE OF THE RED CROSS News Items . . . . . . . . . . . . . . . . . . . . . . . . . . 19

The ICRC Tracing Service in the Congo (Ed. L.J.) . . . . . . . 31

ICRC activities in Algeria . . . . . . . . . . . . . . . . . . 38

Joint Commission of the Empress Shôken Fund . . . . . . . . . 40

INTERNATIONAL RED CROSS

Standing Commission of the International Red Cross . . . . . . . 43

\section{MISCELLANEOUS}

Social Service in a changing world (M.-L. Cornaz) . . . . . . . 44

World Heallh Day . . . . . . . . . . . . . . . . . . . . . 49

BOOKS 


\section{SPANISH}

Informaciones del mundo entero. - La actividad del CICR en Argelia. Comisión permanente de la Cruz Roja Internacional.

\section{GERMAN}

Nachrichten aus Nah und Fern. - Tätigkeit des IKRK in Algerien. Ständige Kommission des Internationalen Roten Kreuzes.

\section{THE}

INTERNATIONAL REVIEW OF THE RED CROSS

is published each month by the International Committee of the Red Cross

7, Avenue de la Paix, Geneva, Switzerland Postal Cheque No. I. 1767

Annual subscription : Sw. fr. 20.- Single copies Sw. fr. 2.- 